\title{
Assessing the Role of Higher Education in Developing Social Entrepreneurship in Malaysia: A Review of Literature
}

\author{
Hamdan Said1 \\ lqbal Ahmad² \\ Masdinah Alauyah Md Yusof ${ }^{3}$ \\ Ahmad Jusoh 4 \\ 1,2,3,4 Universiti Teknologi Malaysia \\ 1p-hamdan@utm.my, 2shahnavi777@hotmail.com, 3alauyah@utm.my, ${ }^{4}$ ahmadj@utm.my
}

\section{Doi:10.5901/mjss.2015.v6n2p583}

\section{Abstract}

This paper examines the role of higher education in developing social entrepreneurship in Malaysia. Higher education institutions are social industries. They prepare important social capital for the society. Presently, the concept of social entrepreneurship is becoming popular all over the world. In response to this trend, the higher education has also shifted its attention towards using higher education as a means to promote social entrepreneurship. Few studies have explored this phenomenon. For this purpose, an examination of the existing literature was carried out to find answer to the main question that how higher education institution is responding to the need of development of social entrepreneurship. The findings of the review show that although the concept of social entrepreneurship is still in its infancy stage in Malaysia but it is increasingly gaining attention. Interestingly, the higher education institutions are providing suitable foundation for the development and promotion of social entrepreneurship in the country. However, in this regard, the paper found lack of financial support to higher education institutions for the development of social entrepreneurship. To overcome this situation, the paper suggests that higher education institutions may be used as a suitable platform for promotion of social entrepreneurship. The paper concludes that the future of economic growth and social development of the society is closely connected with the concept of growing social entrepreneurship in the country. On the basis of this review, the paper recommends that there must be a strong political and financial support for the higher education institutions for the promotion of social entrepreneurship.

Keywords: Higher education, social entrepreneurship, social and economic growth

\section{Introduction}

Social entrepreneurship is deeply embedded in the history of business innovation and economic theories (Oksanen \& Rilla, 2009). Economists have underlined its importance for social emancipation and economic development rather than mere accumulation of wealth. In Malaysia, the history of social entrepreneurship is very short (Yu, 2001; Abidin, \& Bakar, 2005). However, in the development of entrepreneurship, the Malaysian higher education institutions have played an important role (Aiken, 2006; Mustafa \& Kasim, 2010). Studies have shown that the government of Malaysia and its higher education institutions have been working together to increase the impact of higher education on the economy and business (Kothari \& Handscombe, 2007). The country has a world class research base in business ventures, but has not been able to effectively translate its economic goals into reality in the field of social capital development, into business innovation and competitive advantage or social benefits (Kasim, 2011).

Literature has demonstrated that higher education institutions in Malaysia have been making incisive attempts to contribute towards preparation of social capital that could materialize the goals of social welfare and economic emancipation (Othman \& Mansor, 2011). For this purpose, the institutions have been imparting relevant and updated entrepreneurial knowledge to the students to enable them to play a positive role in the development of Malaysian social sector and economy (Mustafa \& Kasim, 2010).

Studies have indicated that several programs were initiated by the government to achieve the targets of social growth and alleviation of poverty, strengthening social justice in the society by exposing graduates to the world of entrepreneurship (Sarif, Ismail \& Sarwar, 2012). Despite of serious efforts and application of a variety of teaching and learning approaches, the number of entrepreneurship produced is limited (Mair \& Martí, 2006; Kassim, 2011). The 
concept of social entrepreneurship is gaining rapid popularity these days in the whole of the world (Austin Wei-Skillern \& Stevenson, 2003). In many cases, researchers argue that there has been less support from the government side, especially in terms of financial support to higher education institutions. Instead the major support for the development of social entrepreneurship has been associated with non-for-profit organizations or for profit or income gaining organizations (Kasim, 2011; Cheng \& Chang, 2004). Studies have explained that social entrepreneurship is characterized by social mission and social service. Wealth is merely used as a means to an end for social entrepreneurship. It is not related to creation of wealth or amassing more money (Bjerke, 2007; Aiken, 2006).

The principles of social entrepreneurship were identified by Joseph Schumpeter a century ago. These qualities are found in individuals who show willingness to contribute towards the development beyond the traditional ways and everyday routines (Hindle, Anderson \&Gibson, 2004). This creates in the individuals a desire to relinquish their personal gains and work for the general welfare and overcome the inner-personal and the social environment (Drayton, 2006). In the current times, social entrepreneurship is considered as a new approach in business. This approach is based on the principle that betterment of the people must be ensured and the life of the people affected by business must be restored to its original joy (Kuratko \& Hodgetts, 2007; Ireland, Kuratko \& Morris, 2006).

Social entrepreneurship is not a new phenomenon. This concept has existed in human society since long time in various forms (Weerawardena, 2006; Dees, Emerson, \& Economy, 2001). However, its emergence in the present century as a new business approach has added new dimensions to the activities of the world of economics. It has been in practice for centuries but its new re-emergence has created new challenges and new opportunities (Light, 2008). Nowadays, there is a wide acceptance of social entrepreneurship around the world (Okpara \& Halkias, 2011). For example, in 1993, in USA, Harvard Business School launched a program namely 'Social Enterprise Initiative' which is considered one of the mile stones of the current times (Defourny \& Nyssens, 2006).

Many training programs were designed and implemented in the United States for promotion of social entrepreneurship. Despite of it, in many countries of the world, the concept of social entrepreneurship remained an ambiguous concept referring to market-oriented economic activities serving a social goal (Rothaemerl, 2007). In rest of Europe, the concept appeared in early 1990s. Formerly, the Europeans associated it with community and voluntary sectors and cooperative ventures in the society (Heinonen \& Hytti, 2010). However, a significant development took place in 2002 when a debate started in the United Kingdom (UK) on social enterprise (Handscombe, 2003; Tajeddini, \& Mueller, 2009). It was the re-engineering of the concept of social enterprise particularly during the Tony Blair government when the 'Social Enterprise Coalition' was launched in order to improve the knowledge of its people on social enterprises and to promote social entrepreneurial activities at national level (Defourny \& Nyssens, 2006).

Social entrepreneurship is not a new concept but it has gained much importance in the present day due to its potential to solve social issues and make a difference in the lives of people (Sandler, 2010). Despite of its high popularity, the field of social entrepreneurship still lacks an enthusiasm for its professionals (Light, 2008). However, in UK context, social enterprises compete in the market place like other normal business ventures. For example, Trees group is one of such social enterprises in the East Midlands having a large turnover and more than 120 staff. The main aim of this group is to support its subsidiary companies in training, regeneration, education, employment and sustainability (Matlay, 2006; Siegel, Wright \& Lockett, 2007; Murphy \& Coombes, 2009).

\section{Methodology}

The main purpose of this paper is to evaluate the role of higher education institutions for development of social entreprenurship in Malaysia. To study this, the present paper adopted literature review as the method of investigation. As discussed above that current research on higher education and social entreprenureship in Malaysia is in its infancy. This area needs more exploration. The crtical review of literature helps in clearly explaning the role of Malaysian higher in promoting social entreprenurship in Malasyia. The paper provides a stronger freamwork for researchers and practitioners to understand the need and implication of social entreprenuriship in Malaysia. The paper also provides some new inights to the managers and administrators regarding the vital of higher edcuation in promoting the social entrepreneurial actvivties.

\section{Social Entrepreneurship and Higher Education}

Social entrepreneurship is an emerging area in higher education (Todorovic, 2004; Defourny \& Nyssens, 2006). There is a need for research in the area of higher education and social entrepreneurship (McElwee \& Atherton, 2005). Basically, social entrepreneurs have a social mission and social objectives to be achieved. Thus the main aim of social 
entrepreneurship is not to maximize the profit of the business, rather, it is to benefit those who are helpless and poor (Drayton, 2006; Chell, 2007). Social entrepreneurism is based on three principles such as (1) a vision, (2) leader, and (3) willingness to contribute towards a social cause (Thompson, Alvy \& Lees, 2000; Dees, 2002). In a previous study, Sarif, Ismail and Sarwar (2012) mentioned that social entrepreneurs contribute toward the growth of an organization in the following three ways (a) envisioning the future state of the organization, (b) giving the vision a direction by mobilizing resources, and (c) using available human and material resources to realize the goals (Rothaemel, Agung \& Jiang, 2007).

Measurement of social entrepreneurs is a difficult task due to the wide ranges of its definitions and its nature. Research has indicated that the fundamental aim of higher education is enhancement of the work skills of individuals and knowledge to enable them to contribute towards the ultimate development of their societies (Robinson \& Malach, 2004). Contrary to this, research has shown that higher education institutions in many countries of the world produce individuals who have less refined work skills (Mustafa \& Kasim, 2010). The current situation demands that universities should produce graduates who have abilities to contribute as effective social capital. This is one of the main goals of the present knowledge societies. For this purpose, university-industry relationship needs to be strengthened. There must be an effective collaboration between university and industry to promote the social goals of education (Martin, \& Turner, 2010).

Entrepreneurial education existed in the past but with different aims and goals than it exists today. For example, a research in early 1980s in the area of entrepreneurship mainly focused on finance, marketing, internationalization and technology aspects of business and development (Handscombe, 2003). There was paradigm shift in later times (Bornstein, 2004). In 1990s, new research began to take interest in 'Human Aspect' of the business rather than the 'Profit Aspect' of the entrepreneurship or business (Rothaemerl, 2007). This concept became very popular topic for studies for researchers in late 90s. However, the entrepreneurial mission has been missing and few universities have adopted it for teaching, research and society (Heinonen \& Hytti, 2010). To better understand the relationship between higher education and social entrepreneurship, there is a need to study the kind of environment prevailing and its dynamics related to the goals of higher education and social enterprises (Martin \& Turner, 2010). To this end, two types of market environments are envisaged: social welfare markets and commercial markets (Bjerke, 2007). The social entrepreneur spectrum is an alternative option that entrepreneurs use to structure their enterprises (Gartner, 1994; Aiken, 2006).

\section{Social Entrepreneurship in Malaysia}

Malaysia is a developing country. Entrepreneurial activities are seen as a means to strengthen the economic and social development, improve distribution of income, stimulate economic growth, and reshape the current economic structure which is largely dependent on firms (Kassim, 2011). Over the years, the Malaysian government has been making intensive efforts to promote home grown business entrepreneurs. For this purpose, the government has been making policies and sincere efforts to encourage entrepreneurial activities and to promote self-employment throughout the country (Cheng \& Chang, 2004). To achieve this aim, the government supported small business enterprises, petty trading, agriculture and services. To provide constitutional support for entrepreneurial activities, Ministry of Entrepreneur and Cooperative Department (MECD) and its agency namely Perbadanan Nasional Berhad (PNS) and Small and Medium Enterprises (SME) bank are working together (Othman \& Mansor, 2011).

\section{Conclusion}

The main purpose of this study was to examine the role of higher education in promotion of social entrepreneurship in Malaysia. The findings of the review study showed that social entrepreneurship is a new concept in Malaysia. However, the concept has been integrated in the higher education in Malaysia. This development has created awareness among the academic circles as well which has led to incorporation of the concept of social entrepreneurship in the curriculum at higher education level. The social entrepreneurship has yet to realize its complete fruition in Malaysia. This may be possible with the support from the government and higher education institutions together.

On the basis of the review of literature it can be concluded that higher education is a good predictor of social entrepreneurship. The findings of this study further support the results of previous studies mentioned above on the benefits of social entrepreneurship. There is lack of literature on social entrepreneurship in the Malaysian context. However, this study attempted to define certain assumptions and made conclusions in a limited sense about the current practices in higher education of Malaysia regarding social entrepreneurship. Furthermore, this study also creates some room for further research in the area of social entrepreneurship in Malaysian context. 


\section{Future Research}

This paper investigated and discussed the role of higher education institutions in Malaysia in promotion of social entrepreneurship. The study had many limitations. First, it was conducted based on a short amount of available literature on social entrepreneurship in Malaysia. This limits its broader generalization and reliability. However, the paper presents new direction for future research on social entrepreneurship in Malaysian context. It is one of the preliminary researches on social entrepreneurship in Malaysia that adds to the body of literature on social entrepreneurship in Malaysia, specifically, concerning the role of higher education institutions. It was a review paper having its own limitations. It is suggested that future research should adopt other designs to study the concept of practice of social entrepreneurship in Malaysia.

\section{References}

Abidin, F. Z., \& Bakar, H. (2005). Entrepreneurship education: The case of Universiti Utara Malaysia. Sintok: UUM.

Aiken, M. (2006).Towards market or state? Tensions and opportunities in the evolutionary path of three UK social enterprises. In Nyssens, M. (ed.).Social enterprise - At the crossroads of market, public policies and civil society (pp259-271). London: Routledge.

Austin, J., Wei-Skillern, J., \& Stevenson, H. (2003). Social and commercial entrepreneurship: Same, different, or both? Entrepreneurship Theory and Practice, 31(1), 1-22.

Bjerke, B. (2007).Understanding entrepreneurship. Cheltenham: Edward Elgar Publishing.

Bornstein, D. (2004). How to change the world social entrepreneurs and the power of new ideas. Oxford: Oxford University Press.

Cheng, M. Y., \& Chang, C. (2004). Entrepreneurship education in Malaysia. Melaka: Multimedia University, Malaysia.

Chell, E. (2007). Social enterprise and entrepreneurship: Towards a convergent theory of the entrepreneurial process. International Small Business Journal, 25(1), 5-26.

Dees, J.G., Emerson, J., \& Economy, P. (2001). Enterprising nonprofits: A toolkit for social entrepreneurs. Toronto: Wiley \& Sons.

Dees, J. G. (2002). Strategic tools for social entrepreneurs: Enhancing the performance of your enterprising non-profit, non-profit law, finance and management series. Indianapolis, IN: Wiley

Drayton, W. (2006). Everyone a change maker social entrepreneurship's ultimate goal. Innovations, 25(Winter), 80-96.

Defourny, J. \& Nyssens, M. (2006). Defining social enterprise. In Nyssens, M. (ed.), Social enterprise - At the crossroads of market, public policies and civil society (pp. 3-26). New York, NY: Routledge.

Gartner, W. B. (1994). Finding the entrepreneur in entrepreneurship. Entrepreneurship Theory and. Practice, 18(3), 5-10.

Heinonen, J., \& Hytti, U. (2010). Back to basics: The role of teaching in developing the entrepreneurial university. The International Journal of Entrepreneurship and Innovation, 11(4), 283-292.

Handscombe, R. D. (2003). The promotion of an entrepreneurial culture in universities-capturing change in the cultural web. Industry and Higher Education, 17(3), 219-22.

Hindle, K., Anderson, R.B., \& Gibson, B. (2004). From what we know to how we use it: Five principles for turning entrepreneurship research into practitioner action guidelines. Journal of Small Business \& Entrepreneurship, 17(4, Fall), 261-266.

Ireland, R. D., Kuratko, D. F., \& Morris, H. M. (2006). A health audit for corporate entrepreneurship innovation at all levels: part 1, Journal of Business Strategy, 27(1), 10-17.

Kasim, R. S. (2011). Malaysian higher education institutions: Shaping an entrepreneurial agenda. International Journal of Information and Education Technology, 1(2), 163-170.

Kothari, S., \& Handscombe, R. D. (2007). Sweep or seep? Structure, culture, enterprise and Universities. Management Decision, 45(1), 43-61.

Kuratko, D. F., \& Hodgetts, R. M. (2007). Entrepreneurship theory, process, practice. Canada: Thomson South-Western.

Light, P. C. (2008). The search for social entrepreneurship. The Brookings Institution, Washington DC [e-book]

Martin, L., \& Turner, P. (2010). Entrepreneurial universities: The key ingredient in the recipe for UK innovation? Realities of working in business engagement roles in academia. The International Journal of Entrepreneurship and Innovation, 11(4), 273-281.

Mair, J. \& Martí, I. (2006). Social entrepreneurship research: A source of explanation, prediction, and delight. Journal of World Business, 41(1), 36-44.

Matlay, H. (2006). Entrepreneurship education: More questions than answers? Education \&Training, 48(5), 289-295.

McElwee, G., \& Atherton, A. (2005). Publication trends and patterns in entrepreneurship - The case of the international journal of entrepreneurship and innovation. Journal of Small Business and Enterprise Development, 12(1), 92-103.

Murphy, P. J., \& Coombes, S. M. (2009). A model of social entrepreneurial discovery. Journal of Business Ethic, 87(3), 325-336.

Mustafa, W. F. W., \& Kasim, R. S. R. (2010). Entrepreneurial experience in higher education in Malaysia, 2010 international conference on science and social science research (CSSR, 2010). December 5-7, 2010, Kuala Lumpur, Malaysia.

Okpara, J. O., \& Halkias, D. (2011). Social entrepreneurship: An overview of its theoretical evolution and proposed research model. International Journal of Social Entrepreneurship and Innovation, 1(1), 4-20.

Othman, N., \& Mansor, M. (2011).Consulting-based entrepreneurship education in Malaysian higher education institutions. 2011 International Conference on Social Science and Humanity IPEDR vol.5, IACSIT Press, Singapore. 
Oksanen, J., \& Rilla, N. (2009).Innovation and entrepreneurship: New innovations as source for competitiveness in Finnish SMEs. International Journal of Entrepreneurship, 13(Special Issue), 35-48.

Robinson, P., \& Malach, S. (2004). Multi-disciplinary entrepreneurship clinic: Experiential education in theory and practice. Journal of Small Business \& Entrepreneurship, 17(4), 317-332.

Rothaemerl, F. T. (2007). University entrepreneurship: A taxonomy of the literature. Industrial and Corporate Change, 16(4), 691-791.

Rothaemel, F. T., Agung, S. D., \& Jiang, L. (2007). University entrepreneurship: A taxonomy of the literature. Industrial and Corporate Change, 16(4), 691-791.

Sandler, M. R. (2010). Social entrepreneurship in education - private ventures for the public good. Plymouth: Rowman\& Littlefield Education.

Siegel, D. S., Wright, M., \& Lockett, A. (2007). The rise of entrepreneurial activity at universities: Organizational and societal implications. Industrial and Corporate Change, 16(4), 489-504.

Sarif, S. M., Ismail, Y., \& Sarwar, A. A. M. (2012). Availability of literature on social entrepreneurship for sustainable wealth creation in internet. International Journal Management Research and Review, 2(7), 1087-1103.

Tajeddini, K., \& Mueller, S.L. (2009). Entrepreneurial characteristics in Switzerland and the UK: A comparative study of techno entrepreneurs. International Entrepreneurship, 7(1), 1-25.

Todorovic, Z. W. (2004). The framework of static and dynamic components: An examination of entrepreneurial orientation and university ability to teach entrepreneurship. Journal of Small Business \& Entrepreneurship, 17(4), 300-316.

Thompson, J., Alvy, G., \& Lees, A. (2000). Social entrepreneurship - a new look at the people and the potential. Management Decision, $38(5), 328-338$.

Weerawardena, J. (2006). Investigating social entrepreneurship: A multidimensional model. Journal of World Business, 41(1), 21-35.

Yu, T. F. L. (2001). Towards a theory of the entrepreneurial state. International Journal of Social Economic, 28(9), 752-266. 